\title{
DIFFERENCES IN PURPOSES AND LIFE-GOALS FROM THE PERSPECTIVE OF HEALTH BEHAVIOR IN A ROMANIAN ADOLESCENT SAMPLE
}

Authors:

\author{
Sándor Csibi (PhD.) \\ University of Medicine, Pharmacy, \\ Science and Technology \\ (Targu Mures, Romania) \\ Mónika Csibi (PhD.) \\ University of Medicine, Pharmacy, \\ Science and Technology \\ (Targu Mures, Romania)
}

E-mail adress of the first author: csibi.sandor@umftgm.ro.

\section{Lectors:}

\author{
Pașca Maria Dorina (PhD.) \\ University of Medicine, Pharmacy, \\ Science and Technology \\ (Targu Mures, Romania) \\ Petrika Erzsébet (PhD.) \\ University of Nyíregyháza, \\ Institute of Physical Education \\ and Sport Sciences \\ (Nyíregyháza, Hungary)
}

Csibi S., \& Csibi Mónika (2019): Differences in purposes and life-goals from the perspective of health behavior in a Romanian adolescent sample. Különleges Bánásmód, 5. (1). 19-29.

DOI 10.18458/KB.2019.1.19

\begin{abstract}
The goal of this research was to investigate specific personality factors theorized to be involved in adolescents' health behavior, such as individual differences in the level of purposes in life and the variations of life goals. The instrumentation for the study was a self-completed questionnaire, which included items for assessing health-behavior data, the Purposes in Life scale, and the Aspiration Index for life-goals' assessment. There were 385 teenage study participants aged between 16-18 years (mean $=16.8$ years; 182 boys $-47.3 \%$ and 203 girls $-52,7 \%$ ) in Transylvania, Romania. Results showed that adolescents who engaged in health protective behaviors (e.g., physical activity, fruit /vegetable consumption) reported higher levels of purposes in life and intrinsic life-goals, such as affiliation or personal growth. Conversely, those engaged in health risky behaviors (e.g., substance use, sweet/soft drink consumption) not only reported lower levels in having a purpose in life, but also tended to report fewer health goals for the future as well as personal growth. These findings argue that health professionals should incorporate and emphasize the development of teenagers' life goals and purposes in the design and conceptualization of schoolbased prevention and health promotion programs that focus on fostering healthy life-style adoption.
\end{abstract}

Keywords: purpose in life, life goals, health behavior

Disciplines: psychology, pedagogy

\section{Absztrakt}

EGYÉNI KÜLÖNBÖZŐSÉGEK A SERDÜLŐK EGÉSZSÉGES ÉLETMÓDJÁBAN AZ ÉLETCÉLJAIK PERSPEKTÍVÁJÁBÓL

A kutatás célja azoknak a specifikus személyiségtényezőknek vizsgálata, amelyek szerepet játszanak a serdülők egészséges életmódjában. Eszközök: önkitöltős kérdőív, amely az egészséget védő viselkedésekre vonatkozó kérdéseket tartalmaz, az Életcélok skála, valamint az Aspirációs Index. Résztvevők: 385 tanuló, a 16 és 18 év közötti korcsoportból. Átlag életkoruk 16,8 év volt, nem szerinti eloszlásuk alapján 182 fiú 47,3\% és 203 lány - 52,7\% vett részt a felmérésben. Eredmények: Az egészségvédő magatartást (mint például a fizikai aktivitás, a gyümölcs/ zöldségfogyasztás) tanúsító serdülők magasabb szintú és többnyire belső életcélokról számoltak be, mint amilyenek a személyes növekedés, és affiliáció. Másfelől, az egészségre kockázatot jelentő magatartású (mint például a szerhasználat, az édes/szénsavas üdítőital-fogyasztás) serdülők kevesebb életcélról számoltak be. Eredményeink arra utalnak, hogy a serdülők életcéljai, valamint ezeknek gazdagodása fontos az egészséges életmód elfogadására összpontosító iskolai prevenciós és egészségfejlesztési programok kialakításában és konceptualizálásában.

Kulcsszavak: egészségvédő magatartás, életcélok, serdülők

Diszciplinák: pszichológia, pedagógia 


\section{INTRODUCTION}

Development during adolescence involves the establishing of personality traits, which exert strong influence on later health-related habits and behavioral patterns. Underlying the adoption of healthy behaviors or conversely, the adoption of risky health behaviors appears to be role of the personality components. Research shows that in adolescence, the capacity of reasoning is relatively mature, yet the abilities to regulate emotional and behavioral responses are still in a developing phase and immature (Gibbons, Kingsbury, \& Gerrard 2012).

The literature in this area explains purpose in life as a dominant issue in teenagers' identity development and motivational maturity to dedicate resources toward particular aspirations and goals (Kashdan \& McKnight, 2009). Studies describe purpose as a construct that for adolescents provides a basis for achievement goal-orientation that is an important aspect for becoming cognitively 'mature' (Hill, Burrow, Dell, \& Thornton, 2010). Purposes in life represent a personality construct that is able to provide adolescents with stronger motivation toward constructive learning (see: Mezó \& Mező, 2005, 2014) and reappraisal of healthrelated negative events in an adaptive manner. Other authors have found relevant associations between purposes in life and positive youth development outcomes (Schaefer, Morozink, van Reekum, Lapate, Norris et al., 2013; Damon, 2009).

Research has identified several personality dimensions with relevancy for the study of healthy life-style, including purpose in life, meaning in life, personal goals, fostering self-acceptance, and positive relations with others (Ryff, \& Singer, 2002). It may be concluded that adolescents with high levels of purposes in life also have more highly conceived and thought out life-goals, orientation, consciousness of experiences, and meaning about their present and past life. On the other hand, teenagers who report fewer purposes in life face a lack of meaning in life, fewer life goals or aims (Ryff \& Singer, 2002).

Burrow \& Hill (2011) report that purposecommitment among adolescents is positively associated with positive affectivity, hope, and happiness, and appears to strongly mediate relationships between identity and reported levels of well-being. Thus, a strong sense of purposes in life may serve as an important mechanism through which a stable identity contributes to well-being (Burrow \& Hill, 2011). Furthermore, research supports that more highly conceived and developed purposes in life relate to higher importance given to social, psychological, and health-related goals (Pinquart, Silbereisen, \& Fröhlich, 2009). According to Covington (2000) goal setting plays a significant role in organizing, regulating, and orienting the behavior. The differences in the predominance of goals (intrinsic or extrinsic) and value-system strongly influence adopted behaviors. Furthermore, Ryan, et al. (2008) argue that the sense of meaning and defined purposes in life fostering the personal goal setting are relevant for the processes of internalization and integration, through which a person regulate and sustain health-protective behaviors (Ryan, Patrick, Deci, \& Williams, 2008; note: Mester $(2011,2012)$ highlights the connections among family socialization, future-oriented goals and mental health. Others (e.g. Hanák, 2018; Hanák \& Dorner, 2012) emphasize the role of school to shaping of lifegoals and health protective behaviors). Research confirms that the energy and perseverance of adolescents invested in attaining goals is an important motivational factor in different life-domains, such as learning competencies and academic achievement (Grant \& Dweck, 2003; Mester, 2010). The underlying mechanisms of motivational processes toward initiating and maintaining the favorable behaviors for health can be explained through selfdetermination theory (Deci \& Ryan, 1985).

This general model provides supporting explanations of determinants of health-related behaviors such as physical activity, healthy eating, weight control, and smoking reduction, and others (Deci \& Ryan, 2008). A study by Shilts, Horowitz, \& Townsend (2004) found that adolescents were setting different goals related to their diet and made progresses toward achieving them including positive changes following their personal goals (Shilts, Horowitz, \& Townsend, 2004). Other research also supported that intrinsic goals were associated with better health-status and higher level of well-being (Vansteenkiste, Simons, Lens, Sheldon, \& Deci, 2004). According to Konkoly et al. (2009) meaning in life showed to be significant factor in differentiating daily smokers and nonsmokers. Studies have found that the prevalence of health-risk behavior increases rapidly during early adolescence and reaches a peak in late adolescence (Piko, Skulteti, Luszczynska, \& Gibbons, 2010). Health-protective behaviors, such as healthy diet and the amount of physical activity showed a relevant association with the presence of a meaning in life, which is a comparable construct to purpose in life (Brassai, Piko, \& Steger, 2011). Furthermore, health-related behaviors, such as smoking, diet, and 
physical activity that rely on self-regulation and play an important role in reported level of health and well-being (Ryan, Patrick, Deci, \& Williams, 2008). Empirical research focusing on the risk behavior index for adolescents' use of tobacco and alcohol has found extrinsic life goals as relevant predictors (Williams, Hedberg, Cox, \& Deci, 2000). Results from Pauwlik \& Margitics (2008) showed that intrinsic goals containing health, personal growth and interpersonal relationships are the most powerful individual aspirations (Pauwlik \& Margitics, 2008). It has been described both intrinsic (e.g. health) and extrinsic (e.g., attractiveness) goals are of relevant influence in motivating the adoption of physical activity. (Ryan, Williams, Patrick, \& Deci, 2009). In school environment supporting autonomy in the students' physical activity-related goals led to their higher engagement in leisure-time physical activity even months later (Vansteenkiste, Simons, Soenens, \& Lens 2004).

Thus, the life goals of adolescents represent an important predictor of psychological need satisfaction and concerns related to health behaviors (Kasser \& Ryan, 1996). Ryan et al. (2008) argue that intrinsic goals are congruent with self-reported well-being and health. Among adolescents, it has been observed that extrinsic aspirations are associated with the tendency to engage in unhealthy behaviors, such as smoking or using alcohol (Williams, Cox, Hedberg, \& Deci, 2000). Additional studies show that adolescents who reported using cigarettes had significantly stronger extrinsic goals than their peer who reported nonsmoking. Adolescents characterized predominantly by intrinsic goals inclined to be more autonomous, while a tendency toward extrinsic goals was associated with more risky and fewer healthy behaviors (Deci, \& Ryan, 2008; Williams, Cox, Hedberg, \& Deci, 2000).

In this study, we examined several key indicators of healthy life-style, such as physical activity, healthy diet, and selected risk behaviors in the perspective of purposes and goals among adolescents. The aim of this research was to determine whether the personality components among adolescents, such as purposes in life, structure of goals might be related to their reported health status and healthrelated behavior and whether gender, age, attending school-type and school performance might play a role in these associations. We theorized that these factors would be associated with an increased adoption of health-behaviors, concomitantly with a lower level of health-risk manifestations. The specific hypotheses for the study were the following: 1. The personality factors of level of purposes in life and structure of goals related to health status would differ according to gender, age, school type, and school performances. 2. Adolescents with more defined purposes in life, predominance of intrinsic and health-related goals would adopt health-behaviors, such as more amounts of physical activity and healthy diet, while the dominance of extrinsic goals, the decreased level of healthrelated goals and the lower values of aspiration index are relevantly associated with health-risk behaviors. We also postulated that there would be significant differences by age and gender among the analyzed variables.

\section{METHOD}

\section{Participants}

Subjects in the study were teenage students from Romanian high schools within the Transylvanian area. The total number of participants was 385, 182 boys $(47.3 \%$, ) and 203 girls (52.7\%). Participants were between 16-18 years of age with a mean age of 16.8 years old and were in grades 10-12. The sample was composed of classes from both theoretical (grammar) and vocational (secondary modern/technical) schools. Classes were chosen within schools randomly. It took 40 minutes for participants to complete the questionnaire and surveys were completed during a one-hour class period. We conducted the survey during November-December in the 2013-2014 academic years.

\section{Instruments}

The survey instrument included the Purpose in Life Test (Crumbaugh \& Maholick, 1964) and the shortened version (Martos, Szabó, \& Rózsa, 2006) of the Aspiration Index Scale (Kasser \& Ryan, 1996), containing three subscales: extrinsic goals (fame, appealing image, and financial success), intrinsic goals (personal growth, affiliation, community contribution) and health goals. The Cronbach alpha values for the Aspiration Index Scale (14 items, $\alpha=.81)$ and Purpose in Life Test (20 items, $\alpha=$. 84).

The survey also included items which assessed some of the health-behavioral factors (utilized in HBSC study in Hungary by Németh \& Költő, 2011), such as the quantity of physical activity (based on moderate-to-vigorous physical activity screening measure developed by Prochaska et al., 2001.), healthy diet (more fruit- and vegetable consumption, fewer sweets or sugared soft drinks consume), smoking, alcohol- and drug use. To obtain the quantity of psychical activity, we asked adolescents to report the number of days over the past week that they were physically active for a total of 
at least 60 minutes per day (response options ranged from " 0 day" to "7 days"). Items on the instrument identified how frequently adolescents eat fruit, or consume vegetables (from "never" to "more than once a day"). They were asked how often they consumed sweets (candy or chocolate) or sugared soft drinks (from "never" to "more than once a day"). The frequency of smoking was determined by the question: "How often do you smoke tobacco at present?" (Response options ranged from "I do not smoke" to "every day"). We obtained information about the frequency of excessive alcohol use by asking the question: "Have you ever had so much alcohol that you were really drunk?" (Answers range from "no, never" to "yes, more than 10 time"). The frequency of any kind of drug use was also obtained ("Have you ever taken any kind of drug"?) with the response options ranging from 'never' to "more than 39 times."

The questionnaire also contained items to obtain demographic data from participants for gender, age, school type (theoretical and vocational school) and school performance.

\section{Analysis}

We performed data analyses using the PASW Statistics program version 18. In the first phase, we calculated descriptive statistics and performed the reliability analysis. In the second phase we calculated Spearman rho correlations to determine significant associations between variables, then the variances of health behavioral factors for our sample with Shapiro-Wilkinson test. We used independentsamples t-test or Mann-Whitney U-test for comparative analysis. In the case of some variables where there wasn't a normal distribution, we performed logarithmical transformation. In the last phase, we performed multivariate linear regression analysis for establishing the predictive role of the variables in the study.

\section{RESULTS}

Table 1 presents the health behavior variables included in the study, comparing the Romanian HBSC data and the European HBSC averages. In this first phase, we dichotomized the data with the purpose of comparability with data presented in the HBSC (Health Behaviour in School-aged Children Study (WHO Regional Office for Europe). records (Currie et al., 2012). Upon inspection of the data, we observed more frequent physical activity among boys, and also higher reports of the frequency of smoking and alcohol use. These differences may be explained by differences in age between our participants (mean age: 16,8 years) and the HBSC studies' sample (mean age: 15.1 years).

There were important differences between boys and girls in health behavior found in this study. Boys reported higher frequencies risk behaviors for physical activity, sweets consumption, alcohol use and drug use compared to girls. Girls consumed more fruits in their diet, while boys reported including more vegetables in their diet. Descriptive statistics of personality variables are presented in Table 2.

The personality variables investigated in this study showed significant variance by gender, age, school-type and school performance. Although we did not find differences between girls and boys in the purposes in life scores, we did find gender differences in the subscales of the Aspiration Index. Boys reported more extrinsic goals $(\mathrm{p}=0.001)$, higher orientation toward financial success $(\mathrm{p}=0.021)$, fame $(\mathrm{p}=0.002)$ and appealing image $(\mathrm{p}=0.006)$. Girls gave more importance to intrinsic goals $(\mathrm{p}=0.005)$, affiliation $(\mathrm{p}=0.040)$ and community contribution $(p=0.015)$. There were not differences in health goals, but there was in the total aspiration index where we found higher values among girls $(\mathrm{p}=0.001)$. We found a significant age difference, in life-goals. The 12-th grade students scored higher on health goals (AI-HG) $(\mathrm{p}=0.009)$ compared to their younger peers. Participants attending theoretical school types, showed significantly predominance of intrinsic goals $(\mathrm{p}=0.008)$ (AI-IG) and its subfactors of personal growth $(\mathrm{p}=0.001)$, community contribution $(\mathrm{p}=0.040)$, and aspiration index $(\mathrm{p}=0.044)$.

In addition, health goals $(p=0.019)$ were more characteristic of vocational high school attendees. School performance was found to significantly correlate with intrinsic goals $(\mathrm{p}=0.001)$, especially with the personal growth $(\mathrm{p}=0.001)$, affiliation $(\mathrm{p}=0.041)$, and community contribution $(\mathrm{p}=0.005)$ subscales (AI-IG). The aspiration index $(\mathrm{p}=0.001)$ was also correlated with better school performance. 
KÜLÖNLEGES BÁNÁSMÓD, V. ÉVF. 2019/1.

Table 1. Comparative statistics of health behavioral factors by gender (percentage).

\begin{tabular}{|c|c|c|c|c|c|c|}
\hline \multirow{2}{*}{ Health behavior variables } & \multicolumn{2}{|c|}{ HBSC average data* } & \multicolumn{4}{|c|}{ "Current Study Sample* $(\%)$} \\
\hline & Girls (\%) & Boys $(\%)$ & Girls (\%) & Boys $(\%)$ & $\mathrm{U}$ & $\mathrm{p}^{* * *}$ \\
\hline Physical activity (at least one hour daily) & 10 & 19 & 8 & 21 & 12215.00 & 0.001 \\
\hline Fruit consumption (eat fruit daily) & 35 & 27 & 46 & 34 & 16700.50 & 0.097 \\
\hline Vegetable consumption (eat vegetables daily) & 35 & 26 & 38 & 32 & 18072.00 & 0.708 \\
\hline Sweets consumption (eat sweets daily) & - & - & 37 & 24 & 15134.00 & 0.002 \\
\hline Soft drink consumption (drink soft drinks daily) & 22 & 28 & 24 & 19 & 18355.00 & 0.911 \\
\hline Smoking (at least once a week) & 17 & 19 & 24 & 27 & 18270.00 & 0.828 \\
\hline Alcohol use (have been drunk at least twice) & 29 & 34 & 36 & 62 & 11969.00 & 0.001 \\
\hline $\begin{array}{l}\text { Any kind of drug use (tried consumption at } \\
\text { least once) }\end{array}$ & - & - & 11 & 28 & 15143.00 & 0.001 \\
\hline
\end{tabular}

Table 2. Means and standard deviances of personality related factors by gender.

\begin{tabular}{|c|c|c|c|c|c|c|}
\hline Variables & $\mathrm{N}$ & Min. & Max. & $\begin{array}{c}\text { Mean } \\
\text { (boys/girls) }\end{array}$ & $\begin{array}{l}\text { Std. Deviation } \\
\text { (boys/girls) }\end{array}$ & $\mathrm{p}^{* *}$ \\
\hline Purposes (PIL) & 385 & 20,00 & 140,00 & $103,28 / 100,27$ & $16,34 / 15,81$ & 0,068 \\
\hline Extrinsic goals (AI-EX): & 385 & 6,00 & 30,00 & $21,77 / 20,22$ & $4,88 / 4,38$ & 0,001 \\
\hline -fame & 385 & 2,00 & 10,00 & $6,57 / 5,96$ & $2,06 / 1,81$ & 0,006 \\
\hline -appealing image & 385 & 2,00 & 10,00 & $7,47 / 6,97$ & $1,83 / 1,73$ & 0,002 \\
\hline -financial success & 385 & 2,00 & 10,00 & $7,71 / 7,28$ & $1,87 / 1,78$ & 0,021 \\
\hline Intrinsic goals (AI-IN): & 385 & 6,00 & 30,00 & $24,96 / 25,91$ & $3,42 / 3,19$ & 0,005 \\
\hline -personal growth & 385 & 2,00 & 10,00 & $8,59 / 8,84$ & $1,39 / 1,25$ & 0,062 \\
\hline -affiliation & 385 & 2,00 & 10,00 & $8,75 / 9,03$ & $1,40 / 1,31$ & 0,040 \\
\hline -community contribution & 385 & 2,00 & 10,00 & $7,62 / 8,02$ & $1,70 / 1,50$ & 0,015 \\
\hline Health goals (AI-HG) & 385 & 2,00 & 10,00 & $8,95 / 8,80$ & $1,29 / 1,36$ & 0,280 \\
\hline Aspiration index $(\mathrm{AI})^{*}$ & 385 & $-8,00$ & 17,00 & $3,19 / 5,68$ & $4,64 / 4,67$ & 0,001 \\
\hline
\end{tabular}

* the Aspiration index shows the general goals orientation and it is calculated by the differences between the persons' intrinsic and extrinsic goals (Martos, Szabó \& Rózsa, 2006).

** significance obtained using the independent sample t-test

Analyses found associations between the personality variables and the health behavioral items, and these results are presented in Table 3.

Higher presence of purposes in life (PIL) was significantly correlated with the amount and the frequency of physical activity and with a healthy diet (fruit and vegetable consumption). Health goals (AI-HG) were found to be positively correlated with health behavior related factors, such as the amount of physical activity and healthy diet, and negatively with the amount of substance use. This association appears implicit, since the setting of health-related goals likely manifest in accordance with one's daily behavior.

Other results of the correlation analysis were the relation between the health-related factors and intrinsic and extrinsic goals. Specifically, fruit and vegetable consumption showed significant association with intrinsic goals, physical activity with extrinsic goals, and the health-risk factors of sweets and soft drinks consumption, smoking, alcohol use, and drug initiation with extrinsic goals. These asso- ciations support the idea that both intrinsic and extrinsic goals may exercise positive or negative influence on health-related behavior, yet extrinsic goals are preponderant role-factors in behaviors characterized by risk assuming in daily activities.

Beyond correlation analysis, we performed t-test analysis with the participants' purposes and lifegoals as dependent variables and health-protective behaviors (physical activity, diet) and health-risk behaviors (smoking, alcohol and drug consumption).

To perform these analyses we classified the responses obtained from the quantity of physical activity in two categories: low values (0-3 days in a week), and high values (4-7 days in a week). The healthy diet responses were merged into two variables (fruitand vegetable- consumption / sweets- and carbonated soft drink consumption) and dichotomized into two categories, high consumption (2-3 times weekly to more than once a day) and low consumption (never to 1 times per week). We dichotomized the smoking frequency variable into 
high (at least 1 times per week to daily) and low frequency (never to monthly). Frequency of alcohol consumption variable was dichotomized into high (23 times to more than 10 times) and low frequency (never to once), and frequency of drug consumption into low (never tried) and high values of reported consumption (once to more than 40 times). The results of the two tailed t-test analyses are reported here in Table 4.

These results showed that teenagers engaging in the higher quantity of physical activity scored higher on purposes in life $(\mathrm{t}=3.12 \mathrm{DF}=383$, two-tailed $\mathrm{p}=0.001)$, extrinsic goals $(\mathrm{t}=1.99, \mathrm{DF}=383$, twotailed $\mathrm{p}=0.047)$ and health goals $(\mathrm{t}=1.96, \mathrm{DF}=383$, two-tailed $\mathrm{p}=0.049)$. Adolescents consuming the high level of fruits and vegetables scored significantly higher on purpose in life $(\mathrm{t}=2.51, \mathrm{p}<.018)$, and overall intrinsic goals $(t=3.95, \mathrm{p}<.001)$, as well as intrinsic goals such as personal growth $(\mathrm{t}=4.32, \mathrm{p}$ $<.001)$, affiliation $(\mathrm{t}=2.55, \mathrm{p}<.029)$, community contribution $(\mathrm{t}=2.41, \mathrm{p}<.016)$, and general intrinsic-oriented aspiration index $(\mathrm{t}=2.51, \mathrm{p}<$
.012). Those with a high level of sweets- and carbonated soft drink consumption scored significantly lower on health goals $(t=-1.89, \mathrm{p}<.049)$ and on the extrinsic-oriented aspiration index $(\mathrm{t}=-2.02, \mathrm{p}<.044)$. Those with bigh frequency of smoking (see Table 4) scored significantly higher on purposes in life $(\mathrm{t}=$ $2.38, \mathrm{p}<.018)$, and lower on financial success $(\mathrm{t}=$ $-2.29, \mathrm{p}<.022)$ and higher on community contribution $(\mathrm{t}=2.54, \mathrm{p}<.011)$. Adolescents with high frequency of alcohol use scored lower on extrinsic goals $(\mathrm{t}=-3.70, \mathrm{p}<.001)$, financial success $(\mathrm{t}=-4.08, \mathrm{p}$ $<.001)$, fame $(\mathrm{t}=-2.00, \mathrm{p}<.046)$, appealing image $(\mathrm{t}=-3.25, \mathrm{p}<.001)$ and higher on aspiration index $(\mathrm{t}=3.81, \mathrm{p}<.001)$. Those with a low level of drug consumption (trying at least once any kind of drug) scored significantly lower on extrinsic goal $(t=$ 2.72, $\mathrm{p}<.007)$, financial success $(\mathrm{t}=-3.01, \mathrm{p}<$ $.003)$, appealing image $(\mathrm{t}=-2.28, \mathrm{p}<.023)$, and higher on health goals $(\mathrm{t}=2.44, \mathrm{p}<.016)$ and aspiration index $(t=2.92, \mathrm{p}<.004)$.

Table 3. Correlation coefficients of showing association between variables of Health/risk behavior, Purposes in life, and Aspiration index (extrinsic, intrinsic, health-goals and aspiration index).

\begin{tabular}{|c|c|c|c|c|c|c|}
\hline \multicolumn{7}{|c|}{ Correlations $^{\text {a }}$} \\
\hline Personality factors & $\begin{array}{l}\text { Physical } \\
\text { activity }\end{array}$ & $\begin{array}{l}\text { Fruit and } \\
\text { vegetable } \\
\text { consumes }\end{array}$ & $\begin{array}{c}\text { Sweets and } \\
\text { soft drinks } \\
\text { consumes }\end{array}$ & Smoking & Alcohol use & Drug use \\
\hline \multirow{2}{*}{ Purposes (PIL) } & $230^{* *}$ &, $138^{* *}$ &,- 045 &,$- 125^{*}$ &,- 050 &,- 054 \\
\hline &, 001 &, 007 &, 377 &, 014 & ,331 & ,288 \\
\hline \multirow{2}{*}{ Extrinsic goals: } &, $151^{* *}$ &,- 014 & 081 & 063 & $241^{* *}$ &, $129^{*}$ \\
\hline &, 003 &, 780 & ,113 &, 215 &, 001 &, 011 \\
\hline \multirow{2}{*}{ - fame } &, $110^{*}$ &,- 001 & 036 & ,024 & $133^{* *}$ & ,026 \\
\hline &, 030 & 1,000 & ,482 & ,318 &, 009 & 611 \\
\hline \multirow[b]{2}{*}{ - appealing image } &, $141^{* *}$ &,- 016 & 070 & 027 & $216^{* *}$ & $114^{*}$ \\
\hline &, 005 &, 761 & ,167 &, 598 &, 001 &, 025 \\
\hline \multirow{2}{*}{ - financial success } &, $128^{*}$ & 052 & ,099 &, $123^{*}$ & $262^{* *}$ &, $151^{* *}$ \\
\hline &, 012 &, 313 & ,053 &, 016 &, 001 &, 003 \\
\hline \multirow{2}{*}{ Intrinsic goals: } & ,050 & $225^{* *}$ &,- 069 &,- 051 &,- 035 &,- 027 \\
\hline &, 332 &, 001 &, 175 & ,319 & ,493 &, 597 \\
\hline \multirow{2}{*}{ - personal growth } & ,036 & $210^{* *}$ &,- 035 &,- 011 &,- 055 & 025 \\
\hline & ,483 &, 001 & ,490 & ,829 & ,282 & ,618 \\
\hline \multirow{2}{*}{ - affiliation } &, $104^{*}$ & $158^{* *}$ & 036 & 027 & ,051 &,- 061 \\
\hline &, 042 & ,002 & ,484 & 601 & ,319 & ,230 \\
\hline \multirow{2}{*}{ - community contribution } &,- 007 & $159^{* *}$ &,- 084 &,$- 119^{*}$ &,- 070 &,- 025 \\
\hline &, 890 &, 002 & ,099 &, 020 &, 168 &, 624 \\
\hline \multirow{2}{*}{ Health goals } &, $159^{* *}$ &, $112^{*}$ &,- 079 &,$- 108^{*}$ &,- 059 &,$- 138^{* *}$ \\
\hline &, 002 &, 028 &, 123 &, 034 & ,249 &, 007 \\
\hline \multirow{2}{*}{ Aspiration index } &,$- 112^{*}$ &, $142^{* *}$ &,$- 127^{*}$ &,$- 115^{*}$ &,$- 259^{* *}$ &,$- 159^{* *}$ \\
\hline &, 028 & ,005 & ,013 &, 024 &, 001 &, 002 \\
\hline
\end{tabular}

a Spearman rho bivariate correlation.

*. Correlation is significant at the 0.05 level (2-tailed).

**. Correlation is significant at the 0.01 level (2-tailed).

a. Listwise $\mathrm{N}=385$ 
KÜLÖNLEGES BÁNÁSMÓD, V.ÉVF. 2019/1.

Table 4. T-test analysis of associations between variables of Health/risk, behavior, Purposes in life, and Aspiration index (extrinsic, intrinsic, bealth-goals and aspiration index).

\begin{tabular}{|c|c|c|c|c|c|c|}
\hline \multirow[b]{2}{*}{ Personality factors } & \multicolumn{6}{|c|}{ Health behavior factors } \\
\hline & $\begin{array}{l}\text { Physical } \\
\text { activity }\end{array}$ & $\begin{array}{l}\text { Fruit and } \\
\text { vegetable } \\
\text { consumes }\end{array}$ & $\begin{array}{c}\text { Sweets and } \\
\text { soft drinks } \\
\text { consumes }\end{array}$ & Smoking & Alcohol use & Drug use \\
\hline Purposes (PIL) & $3.21^{* *}$ & $2.51^{* *}$ & -0.45 & $2.38^{* *}$ & 1.92 & 1.32 \\
\hline Extrinsic goals: & $1.99^{*}$ & 0.19 & 1.44 & -0.93 & $-4.37^{* *}$ & $-2.72^{* *}$ \\
\hline - fame & 1.38 & -0.01 & 1.20 & 0.10 & $-2.63^{* *}$ & -1.57 \\
\hline - appealing image & 1.77 & -0.22 & 0.69 & -0.20 & $-3.67^{* *}$ & $-2.28^{*}$ \\
\hline - financial success & 1.85 & 0.72 & 1.71 & $-2.29^{*}$ & $-4.70^{* *}$ & $-3.01^{* *}$ \\
\hline Intrinsic goals: & 0.16 & $3.95^{* *}$ & -0.88 & 1.31 & 1.61 & 0.38 \\
\hline - personal growth & 0.39 & $4.32^{* *}$ & -0.14 & 0.72 & 1.66 & -0.87 \\
\hline - affiliation & 0.84 & $2.20^{* *}$ & -1.12 & -0.43 & 0.27 & 0.56 \\
\hline - community contribution & -0.69 & $2.41^{* *}$ & -0.87 & $2.54^{* *}$ & 1.72 & 1.03 \\
\hline Health goals & $1.96^{*}$ & 0.04 & $-1.97^{*}$ & 1.53 & 0.86 & $2.44^{* *}$ \\
\hline Aspiration index & -1.81 & $2.45^{* *}$ & $-2.02^{*}$ & 1.82 & $5.46^{* *}$ & $2.92^{* *}$ \\
\hline
\end{tabular}

These results support the assumption that the higher level of intrinsic goals (personal growth, affiliation, and community contribution), the health goals, and purposes in life influence in a positive manner the adolescents' health-related behavior. In order to establish the predictive role of the variables of interest in this study, we conducted multivariate linear regression analysis.

Table 5 presents regression estimates for the personality variables (extrinsic goals, intrinsic goals and aspiration index) and demographic and personal variables (age, gender, school type, school performance) as control variables in the models. Health behavior variables were dependent variables in the regression analyses, while the personality factors were treated as independent variables. Purposes in life were significant predictors of the amount of physical activity (as a strong positive predictor) and of smoking (as a negative predictor) among the health behaviors. Among extrinsic goals, appealing image was positive predictor of alcohol use and consumption of sweets/soft drinks, and financial success (both extrinsic goals) was a positive predictor of alcohol use, and smoking. In the case of intrinsic goals, personal growth was a positive predictor of fruit and vegetable consumption, and a negative predictor of smoking and drug use. Affiliation (intrinsic goal) was a positive predictor of physical activity and a negative predictor of alcohol use. Concerning health goals, they were found to be strong negative predictors of all the health risk behavioral factors (sweets and soft drinks consumption, smoking, alcohol use, and drug use).

Among the control variables, age was associated with alcohol and drug use (as a positive predictor), while gender was a significant predictor in physical activity (as a negative predictor) and alcohol and drug use (as a positive predictor). School type was found to be a positive predictor of the sweets and soft drinks consumption and smoking. School performance was a negative predictor of smoking. The predictors included in the models explained 16\% (physical activity), $8 \%$ (fruit and vegetable consumption), 9\% (sweets and soft drinks consumption), 16\% (smoking), 23\% (alcohol use), and 12\% (drug use) of the total variance.

The study results suggest that extrinsic goals and its subscales (financial success, fame, and appealing image), certain purposes in life, lower health goals, and an extrinsic-oriented aspiration index are likely to exert a significant role in health-related behaviors. 
Table 5. Multivariate linear regression analysis of the personality variables and the health-behavior factors.

\begin{tabular}{|c|c|c|c|c|c|c|}
\hline $\begin{array}{l}\text { Independent Vari- } \\
\text { ables }\end{array}$ & Physical activity & $\begin{array}{l}\text { Fruit and vege- } \\
\text { table consump- } \\
\text { tion }\end{array}$ & $\begin{array}{l}\text { Sweets and } \\
\text { soft drinks } \\
\text { consumes }\end{array}$ & Smoking & Alcohol use & Drug use \\
\hline Purposes (PIL) & $4.09^{\mathrm{a}^{* * *}}$ & 1.42 & 0.14 & $-1.92^{*}$ & -0.71 & -1.37 \\
\hline Fame (AI-EG) & -0.14 & -1.06 & -0.34 & -1.00 & -1.26 & -1.32 \\
\hline $\begin{array}{l}\text { Appealing image } \\
\text { (AI-EG) }\end{array}$ & 0.98 & -1.19 & $0.14^{*}$ & 0.81 & $2.34^{* *}$ & 1.48 \\
\hline $\begin{array}{l}\text { Financial success } \\
\qquad(\text { AI-EG })\end{array}$ & 0.60 & 1.12 & 1.83 & $2.06^{*}$ & $3.74^{* * *}$ & 1.27 \\
\hline $\begin{array}{c}\text { Personal growth } \\
\text { (AI-IG) }\end{array}$ & -1.08 & $2.08^{*}$ & 0.55 & $-2.17^{*}$ & -0.64 & $-2.00^{*}$ \\
\hline Affiliation (AI-IG) & $1.89^{*}$ & 1.24 & -0.28 & 1.19 & $-2.16^{*}$ & -0.81 \\
\hline $\begin{array}{l}\text { Community con- } \\
\text { tribution } \\
\text { (AI-IG) }\end{array}$ & -1.36 & 1.51 & -1.47 & -1.47 & -0.22 & 0.63 \\
\hline $\begin{array}{l}\text { Health goals } \\
\text { (AI-HG) }\end{array}$ & 1.31 & 1.10 & $-2.04^{*}$ & $-3.09^{* *}$ & $-3.75^{* * *}$ & $-3.57^{* * *}$ \\
\hline Age & -0.15 & -1.81 & -1.33 & 0.91 & $2.32^{* *}$ & 1.48 \\
\hline Gender & $-4.86^{* * *}$ & 0.57 & $3.00^{*}$ & 0.71 & $-6.19^{* * *}$ & $-4.87^{* * *}$ \\
\hline School type & -0.28 & 0.19 & $1.88^{*}$ & $2.23^{*}$ & 0.06 & -0.98 \\
\hline $\begin{array}{l}\text { School perfor- } \\
\text { mance }\end{array}$ & -0.73 & -1.08 & -1.89 & $-4.00^{* * *}$ & -1.50 & -0.66 \\
\hline Constant & 1.03 & $3.21^{* * *}$ & $3,53^{* * *}$ & 1.19 & 0.61 & 1.51 \\
\hline $\mathrm{R}^{2}$ & $0.16^{* * *}$ & $0.08^{* * *}$ & $0.09^{* * *}$ & $0.16^{* * *}$ & $0.23^{* * *}$ & $0.12^{* * *}$ \\
\hline
\end{tabular}

\section{DISCUSSION}

The first hypothesis of this study was the presumption that personality-related factors would differ according to the participating teenagers' gender, age, school-type and school performances.

Our analyses supported that extrinsic goals were more important for boys predominantly in the case of financial success, fame and the appealing image subscales, while girls reported significantly higher tendency toward intrinsic goals, such as the affiliation and community contribution subscales. Health goals did not show significant differences, but girls scored higher on the intrinsic-oriented aspiration index.

We observed relevant differences in the healthrelated behavior between girls and boys. Boys reported higher frequency in the level of physical activity, sweet consumption and alcohol use. In comparison, girls were more likely to try drugs, and to consume fruits in their diet. Studies with Hun- garian samples have found that concerning intrinsic aspirations, health goals and interpersonal relationships were the most important for females, while for males, personal growth was the most salient aspiration (Pauwlik, \& Margitics, 2008; Williams, Hedberg, Cox, \& Deci, 2000). We also found significant differences regarding the participants' age in terms of health goals, with higher scores among the students from 12th class. Regarding school type, we found significantly higher value that ascribed to intrinsic goals and their factors such as personal growth, community contribution, and on the aspiration index among students from grammar schools, while health goals proved to be more characteristic of those from secondary technical schools. Those with the highest level of school performances reported more intrinsic goals, especially on the personal growth, affiliation and community contribution subscales, with the exception of higher values on the inward-oriented aspiration 
index. When it comes to differences in school performances and the perspective of purposes and goal, researchers have identified that commitment to personal growth and the having highly intrinsicoriented life goals is highest among high academic achievers (Bronk, Finch, \& Tasneem, 2010). Thus, the obtained results in this study support our first hypothesis.

The second hypothesis postulated that adolescents reporting having defined purposes in life, and intrinsic and health-related goals, would adopt more healthy behaviors (e.g., frequent physical activity and healthy eating). Having extrinsic goals was believed to decrease the level of health-related goals and the lower values on the aspiration index would relevantly be associated with health-risk behaviors. This study determined associations between selected personality variables and health behavior items. Our analyses revealed that having purposes in life was related positively with the amount of physical activity and healthy diet (fruit and vegetable consumption). Health goals showed a positive correlation with health behavior factors, such as the amount of physical activity and having a healthy diet. Studies highlight the importance of diet and its influence on health among adolescents (Jacka, Kremer, Berk, de Silva-Sanigorski, Moodie et al., 2011). Our results support that there is a relationship between intrinsic goals and fruit and vegetable consumption, and also a relationship between extrinsic goals and physical activity, sweets and soft drinks consumption, smoking, alcohol use, and drug use. Previous studies have concluded that there is an association of adolescent risk-behavior and the adoption of a more unhealthy diet and the lack of physical activity, as well as poorer perceptions about physical and mental health (Dube, Thompson, Homa, \& Zack, 2013). In our sample, teenagers with highly defined purposes in life and who set extrinsic and health goals were the most likely to adopt a lifestyle involving physical activity. The t-test results for high level of fruit and vegetable consumption showed significant relationship with purpose in life, intrinsic goals, personal growth, affiliation, community contribution, and intrinsic-oriented aspiration index. Furthermore, health goals and extrinsic-oriented aspiration index were significantly correlated with high level of sweets- and carbonated soft drink consumption. Among the health-risk factors, purposes in life, financial success, and community contribution showed to play a significant role in smoking. Extrinsic goals, such as financial success, fame, appealing image, and aspiration index were significantly associated with a higher frequency of alcohol use. Extrinsic goals, such as financial success, ap- pealing image and health goals, along with an extrinsic-oriented aspiration index showed to play a significant role in trying at least once any kind of drug. We can conclude that higher level of intrinsic goals might exert an important role in adolescents' healthy diets, and also the intrinsic goals subscales (personal growth, affiliation, and community contribution), health goals, and purposes in life. Importance of extrinsic aspirations proved to be a negative predictor while the tendency toward intrinsic aspirations was a positive predictor of purposes in life. Findings from other authors also indicate that intrinsic and extrinsic life goals were predictors of well-being and purposes in life (Wu, Rose, \& Bancroft, 2006).

According to the results of the regression analysis, the purpose in life variable was a significant predictor of physical activity (as a strong positive predictor) and smoking (as a negative predictor). Among extrinsic goals, appealing image was a positive predictor of alcohol use and financial success (both extrinsic goals) was a contributor for alcohol use and smoking. Personal growth, as an intrinsic goal, was a positive predictor of fruit and vegetable consumption, and a negative predictor of smoking and drug use, while affiliation was a positive predictor of physical activity and a negative predictor of alcohol use. The health goals variable manifested as a strong negative predictor of the health-risk behavioral factors, such as sweets and soft drinks consumption, smoking, alcohol use, and drug use. Studies investigating adolescent health-behavior have found that among risk behaviors, smoking was significantly related to stronger extrinsic aspirations, and these aspirations were relevant predictors of tobacco, alcohol, and drug consumption (Deci \& Ryan, 2008). In their explanation, the authors emphasized that orientation toward extrinsic goals implied short-term need satisfaction and risk adoption, while the pursuit of intrinsic goals determined long-term goals and aspirations as well as health behavior (Martos \& Kopp, 2012). Thus, the previously presented and discussed results confirm our second hypothesis.

Our study showed that the health-risk behaviors bear a relevant influence through the predominance of extrinsic goals and its subscales (financial success, fame, and appealing image), fewer defined purposes in life, lower health goals, and an extrinsic-oriented aspiration index. Nevertheless, the cross-sectional study design does not permit us to conclude that these findings are cause-and-effect relationships, and this is an important limitation of our study. Another limitation of our study is the narrow age distribution, which might bias the reported age differences. However, our findings are 
important because they challenge professionals who design and implement school healthpromotion programs to consider the teenage personality aspects when developing strategies and activities targeting improvements in dietary and physical activity or the avoidance of health-related risk-behaviors.

Aknowledgment: This paper is based on the study authored by Csibi et al. (2016) published in a printed volume in Hungarian language.

\section{REFERENCES}

Brassai, L., Piko, B.F., \& Steger, M.F. (2011). Meaning in life: Is it a protective factor for adolescents' psychological health? International Journal of Behavioral Medicine, 18, 44-51.

Bronk, K.C., Finch, H.W., \& Tasneem, T.L. (2010). Purpose in life among high ability adolescents. High Ability Studies. 21, 133-145. doi: 10.1080/13598139.2010.525339.

Burrow, A.L., \& Hill, P.L. (2011). Purpose as a form of identity capital for positive youth adjustment. Developmental Psychology, 47, 1196-1203. doi:10.1037/a0023818.

Covington, M.V. (2000). Goal theory, motivation, and school achievement: An integrative review. Annual Review of Psychology, 51, 171-200.

Crumbaugh, J., \& Maholick, L. (1964). An experimental study of existentialism: The psychometric approach to Frankl's concept of noogenic neurosis. Journal of Clinical Psychology, 20, 200-207.

Currie, C., Zanotti, C., Morgan, A., et al., (Eds.) (2012). Social determinants of health and wellbeing among young people. Health Behaviour in Schoolaged Children (HBSC) study: international report from the 2009/2010 survey. (Health Policy for Children and Adolescents, No. 6)., WHO Regional Office for Europe, Copenhagen.

Csibi S., Pikó B., Csibi M., Page R. M. (2016). Életcélok és aspirációk összefüggéseinek vizsgálata egészségmagatartási tényezőkkel serdülők csoportjában. In Csibi S. \& Csibi M. (szerk.): Aktuális kérdések és alkalmazások az orvosi pszichológia területéról. Ábel Kiadó, Kolozsvár. 12-27.

Damon, W. (2009). Path to purpose: How young people find their calling in life. New York: Free Press.

Deci, E.L., \& Ryan, R.M. (2008). Facilitating optimal motivation and psychological wellbeing across life's domains. Canadian Psychology, 49, 14-23.

Deci, E.L., \& Ryan, R.M. (1985). Intrinsic motivation and self-determination in buman behavior. New York, NY: Plenum.
Dube, S.R., Thompson, W., Homa, D.M., \& Zack, M.M. (2013). Smoking and Health-Related Quality of Life Among U.S. Adolescents. Nicotine \& Tobacco Research, 15, 492-450.

Gibbons, F.X., Kingsbury, J.H., \& Gerrard, M. (2012). Social-psychological theories and adolescent health risk behavior. Social and Personality Psychology Compass 6, 170-183.

Grant, H., \& Dweck, C.S. (2003). Clarifying achievement goals and their impact. Journal of Personality and Social Psychology, 85, 541-553.

Hanák, Zs. (2018): Végzettség nélküli iskolaelhagyás prevenciója megújuló pedagógusképzési program segítségével. (Prevention of school leaving without qualifications through a renewable teacher training program) Képzés és Gyakorlat: Training and Practice 16: 2 p. 65-76 (2018)

Hanák, Zs., \& Dorner, L. (2012): Adaptation analysis of some alternative competencebased education programs' in a Hungarian publik school. Journal of Baltic Science Education 39: 39 pp. 52-61. Paper: 986483, $10 \mathrm{p}$.

Hill, P.L., Burrow, A.L., O’Dell, A.C. \& Thornton, M.A. (2010). Classifying adolescents' conceptions of purpose in life. The Journal of Positive Psychology: Dedicated to furthering research and promoting good practice, 5, 466-473, doi: 10.1080/17439760.2010.534488.

Jacka, F.N., Kremer, P.J., Berk, M., de SilvaSanigorski, A.M., Moodie, M., et al. (2011). A Prospective Study of Diet Quality and Mental Health in Adolescents. PLoS ONE 6, 9, e24805. doi:10.1371/journal.pone.0024805.

Kashdan, T.B., \&, McKnight, P.E. (2009). Origins of Purpose in Life: Refining our Understanding of a Life Well Lived. Psychological Topics, 18, 303316.

Kasser, T., \& Ryan, R.M. (1996). Further examining the American dream: Differential correlates of intrinsic and extrinsic goals. Personality and Social Psychology Bulletin, 22, 280287.

Konkoly Thege, B., Bachner, Y.G., Martos, T., \& Kushnir, T. (2009). Meaning in life: Does it play a role in smoking? Substance Use \& Misuse, 44, 1566-1577.

Martos, T. \& Kopp, S.M. (2012). Life goals and well-being: Does financial status matter? Evidence from a representative Hungarian sample. Social Indicators: Research An International and Interdisciplinary Journal for Quality-of-Life Measurement, 105, 561-568. doi 10.1007/s11205-011-9788-7.

Martos, M., Szabó, G., \& Rózsa, S. (2006). Az Aspirációs Index rövidített változatának pszichometriai jellemzői hazai mintán (Psychometric characteristics of the shortened Aspira- 
tion Index in a Hungarian sample). Mentálhigiéné és Pszichoszomatika 7, 171-191. doi: 10.1556/Mentál.7.2006.3.2. (in Hungarian).

Mester, D. (2010). A tanulási motiváció fejlesztésének új lehetôségei. (New possibilities of development of learning motivation). Pedagógusképrés, 8,37, 87-97.

Mester, D. (2011). A szülői nevelés, igazságosságmotívum és a mentális egészség szerepe föiskolás lányok jövő orientációjának alakulásában. (The role of parental nurturing, the motive of justice and the mental bealth in the forming of future-orientation of college girls) Alkalmazott Pszichologia, 3, 22-45.

Mester, D. (2012). Impacts of family socialization on young adults' future-oriented goals. Erdélyi Pszichológiai Szemle, 2, 165-190.

Mező, F., \& Mező, K. (2005): Tanulási stratégiák fejlesztése az IPOO-model alapján (Development of learning strategies on base of IPOO-mode). Debrecen $(\mathrm{Hu})$ : Pedellus Novitas kft.

Mező K., \& Mező F. (2014): The IPOO-model of creative learning and the students' information processing characteristics. Horizons of Psychology, 23, 136-144.

Németh, Á., \& Költő, A., (Eds.) (2011). Serdülökorú fiatalok egészsége és életmódja 2010 (Health and lifestyle of teenager youth in 2010). Országos Gyermekegészségügyi Intézet, Budapest. (in Hungarian).

Pauwlik, Zs., \& Margitics, F. (2008). Személyes törekvések kapcsolata a szubjektív jólléttel fôiskolai hallgatóknál (Relationships between personal aspirations and subjective wellbeing among college students). Mentálbigiéné és Pszichoszomatika 9, 1-33. doi: 10.1556/Mentál.9.2008.1.1 (in Hungarian).

Piko, B.F., Skulteti, D., Luszczynska, A., \& Gibbons, F.X. (2010). Social orientations and adolescent health behaviors in Hungary. International Journal of Psychology, 45, 12- 20.

Pinquart, M., Silbereisen, R.K., \& Fröhlich, C. (2009). Life goals and purpose in life in cancer patients. Support Care Cancer 17, 253-259. doi: 10.1007/s00520-008-0450-0.

Ryan, R.M., Patrick, H., Deci E.L., \& Williams, G.C. (2008). Facilitating health behaviour change and its maintenance: Interventions based on Self-Determination Theory. The European Health Psychologist, 10, 2-5.

Ryan, R., Williams, G., Patrick, H., \& Deci, E. (2009). Self-determination theory and physical activity: the dynamics of motivation in development and wellness. Hellenic Journal of Psychology, 6, 107-124.

Ryff, C.D., \& Singer, B. (2002). From social structure to biology. Integrative science in pursuit of human health and well-being. In Snyder, C.R., \& Lopez, S.J. (Eds), Handbook of Positive Psychology (pp.541-555). Oxford University Press, New York.

Schaefer, S.M., Morozink Boylan, J., van Reekum, C.M., Lapate, R.C., Norris, C.J., et al. (2013). Purpose in life predicts better emotional recovery from negative stimuli. PLOS ONE 8, 11, e80329, doi:10.1371/journal.pone.0080329.

Shilts, M.K., Horowitz, M., \& Townsend, M.S. (2004). Goal setting as a strategy for dietary and physical activity behavior change: A Review of the literature. American Journal of Health Promotion 19, 81-93.

Williams, G.C., Cox, E.M., Hedberg, V.A., \& Deci, E.L. (2000). Extrinsic life goals and health-risk behaviors in adolescents. Journal of Applied Social Psychology, 30, 1756-1771.

Wu, T.-Y., Rose, S.E, \& Bancroft, J.M. (2006). Gender differences in health risk behaviors and physical activity among middle school students. The Journal of School Nursing 22, 25-31, doi:10.1177/10598405060220010501. 